becomes by this discovery the oldest living type of vertebrata. E. D. COPE.

Philadelphia, Feb. 28.

\section{Artificial production of rain.}

I give below an instance which came under my own observation, of the artificial production of rain, which may be interesting, read in connection with the article in Science, No. 55 .

Many years ago, during my residence in Virginia, the whole of the eastern portion of that state had been suffering one summer from a long-continued drought. For several months not enough rain had fallen at any one time to moisten the ground to the depth of half an inch. The atmosphere was gray, and full of dust. The sun, even at noonday, was 'shorn of his beams,' and could be looked at directly without paining the eyes. 'The temperature was not unusually high; but the weather was very oppressive, being what is called in the country, 'muggy.' One of my neighbors had several months before cut down, and left lying where it fell, a young forest of scrub pines from a field of about forty acres in extent. These pines had, of course, become, during the long drought, completely dry. One August morning, the meteorological conditions remaining exactly as they had been for months before, my neighbor caused fire to be set to this clearing at several points on the circumference at the same time. The fire ran over the whole tract with wonderful rapidity. An immense column of inky smolie rose perpendicularly (there was no wind) to a great height. Upon reaching a stratum of air of its own density, the black column spread out horizontally into the form of a gigantic mushroom, rapidly changed color from jet black to gray, and soon thunder was heard in the top of the ascending and spreading column. The fuel was gradually consumed, and the smoke ceased; but the cloud continued to spread, and rain began to fall in a little more than an hour from the time the clearing was fired.

The thunder gradually ceased; but rain continued to fall until sunset, when the sky cleared. For the remainder of the season, showers and rain-storms occurred with ordinary frequency, as if the conditions favorable to the continuance of the drought had been permanently broken up. Observations of temperature, the dew-point, and of the barometer, would have been valuable; but I had unfortunately no instruments at hand for obtaining them.

While the artificial production of rain can have no economical importance, - depending, as it necessarily must, upon many meteorological conditions, which, to be effectual, must be synchronous, - yet an example of a rainfall of several hours' duration, which was undoubtedly produced by an ascending column of heated air artificially supplied, seems worthy of record.

Annual growth of the 'Tree of heaven.'

I have in the cabinet of Cumberland university two remarkable shoots of Ailanthus glandulosus, Desf., a description of which may be of interest to botanists. They grew in a lot near one of the university buildings during the summer of 1883 . They sprang from small stumps, and are entirely the growth of one season. They give the following measurements:-

No. 1. - Length, 10 feet 6 inches; circumference at base, 5.1 inches; circumference at middle, 4.13 inches.

No. 2. - Length, 11 feet 1.5 inches ; circumference at base, 4.1 inches; circumference at middle, 3 inches.

Lebanon, Tenn

\section{GOUVERNEUR KEMBLE WARREN.}

IN the death of Gen. Gouverneur Kemble Warren of the Corps of engineers, U.S. Army, the country has lost not only one of the ablest military leaders developed by the civil war, but also a scientific man of high attainments, whose life was devoted to profound investigations connected with several of the most important works of internal improvement undertaken by the general government.

He was born on Jan. 8, 1830, at the little village of Cold Spring, upon the Hudson, where his surroundings were all calculated to excite a love for the military service in the mind of an active and intelligent boy. West Point lay in plain sight from his home. The old fieldworks of the revolution, grass grown and crumbling, were associated with his earliest recollections; and the charm thrown by Washington Irving over this classic ground of American history entered into and stimulated his youthful imagination to ideas above the prosaic monotony of every-day life in the nineteenth century. The Mexican war added fuel to the flame; and at the early age of sixteen he sought and obtained an appointment as cadet at the Military academy. He was graduated in 1850 with very high class rank, and was at once assigned to the corps of topographical engineers.

The great problem then beginning to attract attention was the Pacific railroad. The recent discovery of gold in California, and the consequent rush of immigration to the west, demanded increased facilities for transit across the continent; but a broad belt of wilderness, intersected by lofty ranges of mountains, and almost unknown, barred the way. It was in this field that the young officer did his first important scientific work.

Congress made large appropriations for exploring several routes between the Mississippi River and the Pacific Ocean; and the work, under the direction of Gen. (then Capt.) Humphreys, was performed by officers of U.S. engineers. As usual in such cases, the results were expected at once; and Lieut. Warren, who had already shown his ability on the surveys of the Mississippi delta, was detailed as principal assistant in the general office at Washington.

His duties were twofold. He assisted Capt. Humphreys, then laboring under great pressure, in digesting the preliminary reports, in investigating the various problems connected with railroad transportation, in making the comparative estimates of cost, and in preparing 
the general report. His labors were so valuable in this connection that his chief placed their names jointly on the titlepage of what was a very able document. In addition to this work, Lieut. Warren was specially charged with compiling a general map of the entire region covered by the surveys. This labor demanded powers of analysis of a high order. It was needful to thoroughly. study the work of all explorers to date, and, by assigning proper weight to each, to combine the material, often conflicting and discordant, into one consistent and harmonious whole. This task Warren accomplished with surprising success, as has been proved by accurate surveys subsequently extended over much of the ground. His memoir and map, which appeared in the eleventh volume of the final quarto edition of the Pacific railroad reports, will remain a standard authority to ge ographers studying the early history of exploration in that region.

As might naturally be supposed, an ambi-

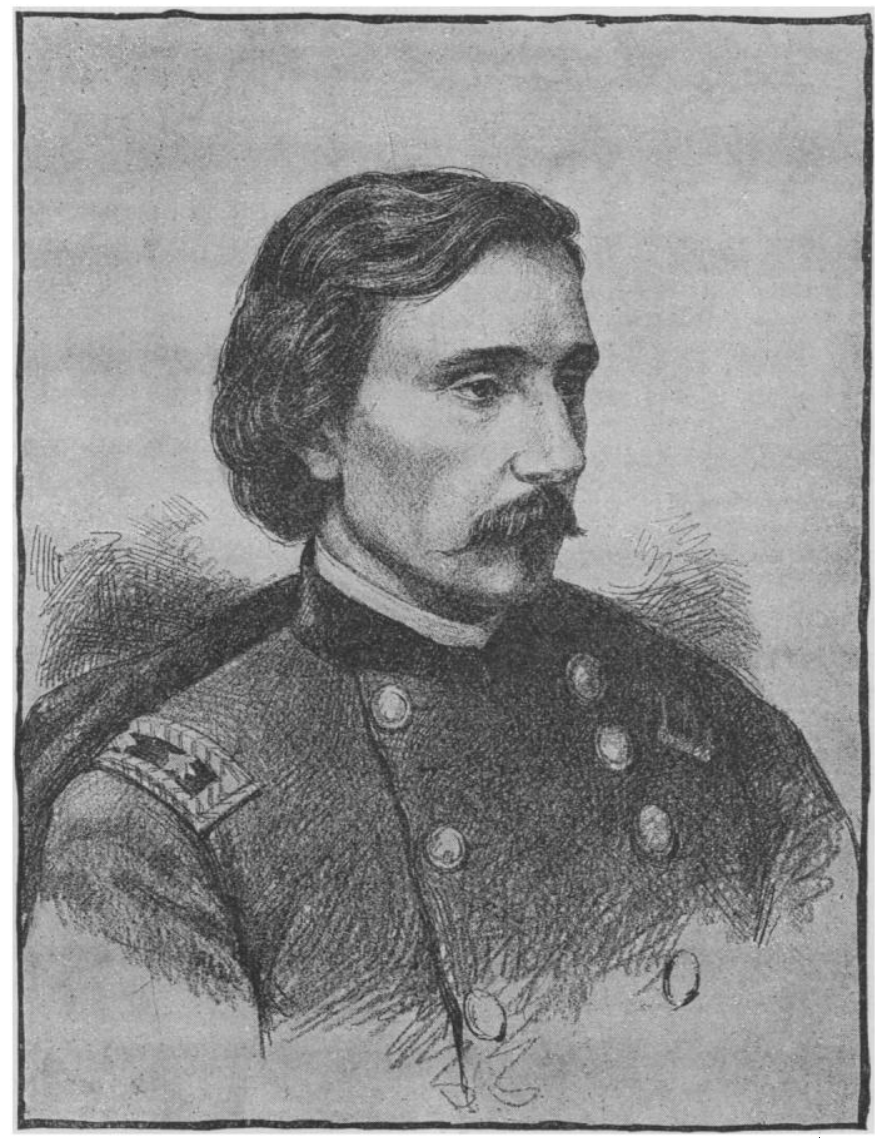
tious young officer would not be satisfied with office-work alone, when laurels were to be won in a field involving no little hardship and risk from the semi-hostile Indian tribes which then roamed unsubdued over the vast plains west of the Mississippi. He sought and obtained di- rection of three separate explorations in Dakota and Nebraska, in the years 1855,1856 , and 1857 ; and, while thus collecting much valuable information needful for opening the country to civilization, he gratified his own strong passion for geological research, and laid the foundation for subsequent generalizations which have attracted the attention of men eminent in that special branch. Space forbids any notice of Gen. Warren's war record here. Suffice it to say, that, entering the volunteer service among the very first of the officers of the regular army (on May 14, 1861), in two years and three months he fought his way from the grade of lieutenantcolonel to that of major-general commanding an army corps. He was present at all the great battles of the army of the Potomac, and was justly regarded as one of the best generals and most gallant officers made known by the war. $\mathrm{He}$ was twice wounded in battle, and had several horses shot under him.

Immediately after the fighting ceased, he returned to duty as major in the Corps of engineers, and soon began to perform an amount of labor in the civil branches of his profession which would have broken down a man of less nervous energy. To simply enumerate the various works with which he was charged between the 
end of the war and the date of his death on Aug. 8, 1882, would extend this notice beyond reasonable limits. They can only be classified and briefly explained.

As an expert in railroad-engineering, Gen. Warren served on three different commissions to inspect and report upon the construction of the Union Pacific and Central Pacific roads and their branches, and to indicate their proper point of junction.

His military experience caused him to be selected to make the detailed surveys of the battle-field of Gettysburg, and of the vicinity of Groveton, Va., in connection with the FitzJohn Porter investigation.

As an hydraulic engineer, his labors covered several of the most important works in the United States, and gave him great eminence. He was a member of the board to report upon the Fort St. Philip canal project, and was president of the commission of engineers appointed by special act of Congress to report upon the best method of protecting the alluvial region of the Mississippi against overflow. $\mathrm{He}$ conducted a very elaborate survey and investigation with a view to improve the navigation of the Fox and Wisconsin rivers; and his report, a model of excellence, has borne the test of practical trial subsequently applied. His surveys and reports upon the improvement of the upper Mississippi and of the Minnesota River are also of standard authority. His name is identified with the improvement of the Connecticut River, and with various harbor improvements upon the coast of Massachusetts, Rhode Island, and Connecticut; and his labor's in hydraulic engineering at other special localities are too numerous to mention.

Gen. Warren also contributed much to the subject of bridge-construction. The Rock Island bridge was built essentially upon his plans and specifications; and his services upon boards ordered to report upon bridges projected or constructed at many important localities involved great labor and research. His reputation in this branch of engineering, however, will chiefly rest upon his monograph upon bridging the Mississippi River between St. Paul and St. Louis. This work was unique in character. The investigation was ordered by Congress to collect data for harmonizing the conflicting interests of navigation and of railroad transportation; and the subject was treated exhaustively, not only from an engineering, but also from a legal point of view. The investigations extended over a period of more than eleven years; and the report is a standard authority to be consulted in any future bridge-projects over navigable western waters.

Gen. Warren's natural fondness for geological research has already been mentioned. His extensive explorations in Dakota and Nebraska ; his numerous surveys for determining the topographical features of the valleys of many rivers in Minnesota, Wisconsin, Iowa, and Illinois ; his investigations in respect to foundations for bridges in this district; and his thorough familiarity with all the geological and topographical reports upon this vast region, and north of it in British America, - enabled him to frame an hypothesis as to geological changes that have occurred, and are now occurring there, which is both novel and brilliant. He first announced it in a paper read at the Chicago meeting of the American association for the advancement of science in 1868, and subsequently elaborated it in his report upon the Minnesota River and in that upon bridging the Mississippi.

Very briefly outlined, it is the following. Lake Winnipeg formerly covered much more space than at present, and extended southward to the head of the Minnesota valley, through which it drained, thus forming the source of the Mississippi. The present outlet to Hudson Bay (Nelson River) did not then exist. The change of drainage has been effected by an elevation of the southern, and a subsidence of the northern, portions of the continent, which have been in slow progress for a vast period of time. When this change began, it caused a decreasing river-slope in the northern portions, and a diminishing power to erode. The resistance due to the granite ledges extending over a hundred miles below Big Stone Lake, in the bed of the upper Minnesota, checked further erosion there, and formed a growing lake above it, which finally found a new outlet to Hudson Bay through the loose drift near Nelson River. This was rapidly eroded, thus reducing the old lake-surface to the present level of Lake Winnipeg, which is about three hundred and sixty feet below the present sources of Minnesota River. Like changes, due to the same cause, by which Lake Michigan has been cut off from the Illinois River, and Lake Winnebago from the Wisconsin River, may be traced.

Gen. Warren discussed this hypothesis in detail, and showed, by so many facts as almost to amount to a demonstration, that, since the glacial epoch, two secular oscillations of this character have occurred in this region. The reasoning is masterly, and illustrates both his breadth of conception, and his care to conclude no farther than the facts warrant.

Although modest and retiring to a fault, the 
earnest scientific work which he had done and was doing was appreciated; and in 1876 he was elected a member of the National academy of sciences. He had long been a member of other learned societies, and was widely known and respected among scientific men.

In person, Gen. Warren was of medium height, and slightly built. His mind was intensely active. Nervous in temperament, and sometimes irritated at trifling annoyances, he became instantly cool and self-poised in times of real danger or difficulty. In close logical reasoning he had few superiors. His mental habits were those of an investigator, - never satisfied until he had studied the matter in hand in all its bearings; but in action he was impetuous, indomitable, and gallant in the extreme. His reading was extensive, both in science and literature, - due largely to his habit of seeking mental rest by working in a new direction. His sense of humor was keen, and his conversation was often brilliant as well as instructive. In disposition he was kindly and sympathetic, and he never failed to give others full credit for whatever good work they had done. He loved justice for its own sake ; and the natural tendency of his mind was always to assist the weak, and to strive to redress wrongs wherever found. 'These traits of character endeared him to his friends; and his memory is cherished with mingled feelings of respect and regard, not easy to express.

Henry L. Abbot.

\section{APPENDAGES OF THE TRILOBITE.}

Through the kindness of Mr. D. A. McCord, the owner of the trilobite described by Professor John Mickleborough (Cinc. journ. nat. hist., vi. 200, 1883), I have had an opportunity to study the original specimen, and prepare a few notes upon it.

When received, the specimens - i.e., matrix and relief - were not free from the grease and dirt acquired in the process of taking casts and frequent handling. On giving them a thorough washing in a solution of potash, this was removed, and also a thin film of decomposed rock on the parts beneath the pygidium. Turning to the laboratory window, to have the sunlight strike across the specimens while still wet, much to my surprise, the appendages shown beneath the pygidium were seen to be of the same character as those beneath the thorax, a number showing in some instances two and three joints attached to the basal joint. On a more careful examination, numerous fine slender filaments were discovered, both beneath the thorax and pygidium, and also near the posterior end of the latter slender jointed appendages not half a millimetre in diameter. Having cut up over two thousand trilobites without discovering any 'branchigerous' appendages beneath the pygidium, other than the spiral and ribbon-like branchial filaments, - such as were attached to the basal joints of the thoracic legs, - naturalists can appreciate the feeling of satisfaction that the discovery of these jointed appendages, so much like those found in cutting sections of Ceraurus and Calymene, gave the writer.

The breaking-apart of the surfaces carrying the legs and their matrix left the legs beneath the thorax in relief; but beneath the pygidium the joints were broken longitudinally, and only a plain outline section is seen. It is probably owing to this that these were overlooked by Professor Mickleborough, and the space beneath the pygidium considered as showing leaf-like or foliaceous appendages. For the purpose of clearly indicating the actual relations of the portion of the Ohio trilobite showing the legs, to the entire dorsal shell of the same species, a figure of the under side of the shell was outlined; and then the Ohio specimen was carefully drawn as if resting in it, as shown in fig. 1 . In the specimens, some of the appendages are shown more distinctly in the matrix, and others in the relief. In the drawing, the two are combined so as to give, without restoration, what is actually present in the specimens. Twenty-six pairs of appendages are clearly discernible. Of these, nine are situated beneath the thorax, one beneath the posterior margin of the head, and sixteen beneath the pygidium. From the character of the appendages beneath the thorax, none of them appear to have belonged to the manducatory apparatus ; the ninth posterior pair having been crowded forward from beneath the pygidium. The anterior pair beneath the head is very imperfect; but sufficient remains to show that these appendages were intimately associated with the cavity of the head, which is now filled with calcite, and they probably represent a portion of the posterior pair of manducatory appendages. In Calymene senaria and Ceraurus pleurexanthemus, the posterior pair of manducatory appendages are always provided with a large basal joint, and undoubtedly the same was the case with other genera of trilobites. The appendages beneath the pygidium are, however, of the greatest interest. I have seen many trilobites, when cutting sections, that had the cephalic and thoracic legs clearly and distinctly defined; but, owing to the small size of the pygidium of Calymene 